\title{
Winter inversion of biomass and activity profile in a marine sediment
}

\author{
Gerhard Graf \\ Institut für Meereskunde, Düsternbrooker Weg 20, D-2300 Kiel 1, Federal Republic of Germany
}

\begin{abstract}
Analysis of marine sediment from Kiel Bight (Baltic Sea) revealed increasing ETS-activity and heat production with increasing sediment depth down to 4 to $7 \mathrm{~cm}$. A subsurface ATP-biomass maximum was found immediately above the $\mathrm{Eh}=+100 \mathrm{mV}$ layer in the sediment. This unusual situation is interpreted in terms of a better adaptation to low temperature by sulfate-respiring bacteria, compared to aerobic organisms in the sediment surface. The sediment showed high oxygen consumption but undetectable respiratory activity as measured by ETS-activity.
\end{abstract}

\section{INTRODUCTION}

Organic matter reaches the seafloor by sedimentation, lateral advection or active incorporation by filter feeders. The lowest degree of degradation, i.e. the highest quality of this food supply, thus occurs in the surface layer of the sediment. Consequently the highest biomass of micro- and meiofauna and the highest activity have been reported for the uppermost sediment layers. At the community level, a biomass profile as well as an activity profile in a sediment must be expected to decrease significantly with depth (Yingst 1978, Bengtsson 1982, Vosjan 1982, Thiel 1983).

In marine sediments a large variety of metabolic pathways has been reported (Fenchel \& Blackburn 1979) and specific processes such as sulfate respiration or denitrification may exhibit very different types of profiles (Sørensen et al. 1979, Jørgensen 1980) with maxima also in deeper sediment layers.

Metabolic activity strongly depends on temperature; this is especially true for respiratory enzymes at low temperatures (Somero et al. 1983). Different types of respiratory enzymes, however, may respond differently to low temperature. Sørensen et al. (1979) reported that the importance of nitrate respiration compared to sulfate and oxygen respiration is greater in winter than in summer. Minimum temperatures in Kiel Bay, our area of investigation, are attained in February, and low activity might be expected during this period. However, a remarkable winter maximum in benthic activity based on sufficient food supply was reported during earlier years (Graf et al. 1982, 1983, Meyer-Reil 1983).
This phenomenon was restricted to the sediment surface; activity in deeper sediment strata was below detection limit. Surprisingly, in early March 1984 we found a situation atypical in terms of redox profile and biomass, and activity pattern in the sediment.

\section{MATERIAL AND METHODS}

RV Littorina cruises (Feb 29, Mar 6 and 23, 1984) were carried out to the 'Hausgarten', a research area in the western Kiel Bay (Baltic Sea). Sediments from $18 \mathrm{~m}$ water depth were sampled using a box corer $(20 \times$ $30 \mathrm{~cm}$ ), and subsamples were collected with plexiglas tubes of $5 \mathrm{~cm}$ inner diameter. The sediment is muddy sand containing ca $2 \%$ organic matter.

Temperature, salinity and oxygen content of the bottom water was measured with probes (Electronic Switchgear, and Yellow Springs Inst. Corp. Model 57). Redox potential of the sediment was recorded with an Eh-electrode (Ingold, Pt-4800-M5) in the laboratory.

For direct calorimetry, $1 \mathrm{~cm}$ slices of the plexiglass cores were placed inside calorimeter chambers and measured at in situ temperature of $2^{\circ} \mathrm{C}$ using the Pamatmat double twin calorimeter (Pamatmat 1978). Thermograms of suboxic and anoxic sediment were not evaluated until a constant heat flow was observed $(6$ to 8 h) (Pamatmat 1982).

Analysis of ATP, ETS-(electron-transport-system) activity and concentration of protein was carried out with sediments combined from 8 plexiglas cores separated into 0.5 to $1 \mathrm{~cm}$ slices. ATP and ETS-activity were 
analysed according to Pamatmat et al. (1981). A more detailed description of the ETS-method, especially for anoxic sediments, is given by Graf \& Bengtsson (1984). Four replicates were run and corrected for chemical reduction. The low activity at in situ temperature required that the incubation time of 5 to $10 \mathrm{~min}$ be extended to $1 \mathrm{~h}$. Protein was assayed according to Lowry et al. (1951) as described by Meyer-Reil (1983).

\section{RESULTS}

Frequent winter storms maintain a homogeneous mixed water column saturated with oxygen down to the sediment. During the investigation period (Feb 29 to Mar 23) temperatures ranged from 1 to $2^{\circ} \mathrm{C}$, salinity was about $16 \%$, and the bottom water - even at the nearest measurable point to the sediment surface - was oxygen saturated. In spite of the high oxygen supply low redox potentials were recorded immediately above the sediment surface (Fig. 1). The only exception was

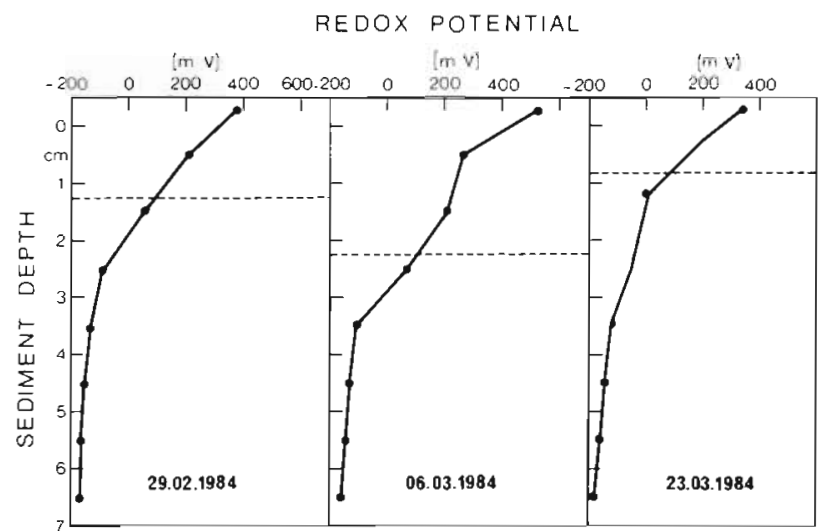

Fig. 1. Redox potential of a marine sediment from Kiel Bight (18 $\mathrm{m}$ water depth). In situ temperature was $2^{\circ} \mathrm{C}$ and bottom water was oxygen saturated. Dashed line: $\mathrm{Eh}=+100 \mathrm{mV}$ layer

March 6 when the water some millimeters above the sediment surface had a redox potential of Eh> $500 \mathrm{mV}$, characteristic for oxygen saturated water. Redox profiles in the sediment indicate anoxic conditions (Eh $\leqq+100 \mathrm{mV}$ ) below $1 \mathrm{~cm}$ sediment depth at the beginning and at the end of the investigation. In the sediments studied the $\mathrm{Eh}=+100 \mathrm{mV}$ depth gives the upper limit for the occurrence of free hydrogen sulfide (Reimers 1976). Only on March 6 was the $\mathrm{Eh}=$ $+100 \mathrm{mV}$ depth deeper than $2 \mathrm{~cm}$ sediment depth, a finding that corresponds to the increased redox potential in the overlying water.

ATP-biomass in the top sediment layers $(0$ to $0.5,0.5$ to $1 \mathrm{~cm}$ ) was in the normal range found during winter (Graf et al. 1982, 1983) and decreased significantly with depth (Fig. 2). Surface sediment values for

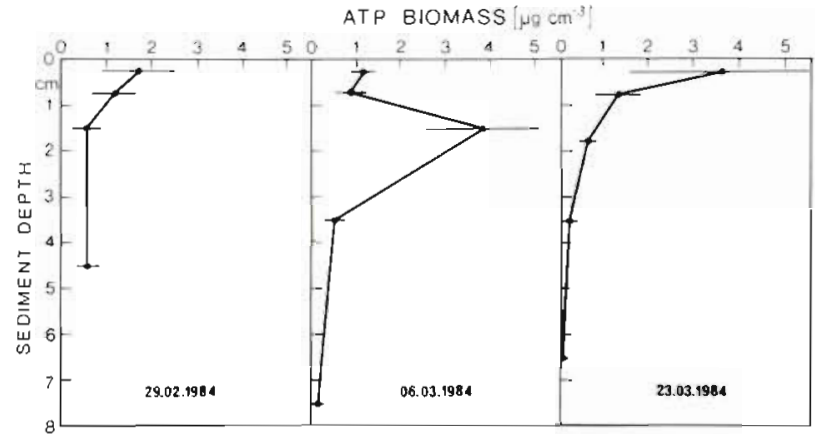

Fig. 2. Development of ATP-biomass $(n=5)$ in the sediment An ATP-biomass maximum is visible immediately above the $\mathrm{Eh}=+100 \mathrm{mV}$ layer on March 6

March 6 also fell within this range. In the 1 to $2 \mathrm{~cm}$ layer, however, an ATP-biomass of almost $4 \mu \mathrm{g}$ ATP $\mathrm{cm}^{-3}$ - the highest value ever found at this station was measured. Even the assumption of an extremely high individual number of meiofauna cannot explain this value. On March 23 the subsurface maximum had disappeared and the extreme value occurred now in the 0 to $0.5 \mathrm{~cm}$ layer.

The corresponding biological activity is also exceptional (Fig. 3). Unfortunately it was not measured on February 29. On March 6, heat release as a measure of overall metabolism was high considering the time of year and increased significantly with sediment depth. Two wk later, the top $2 \mathrm{~cm}$ had not changed (relative to the value measured $2 \mathrm{wk}$ before) while below $2 \mathrm{~cm}$ depth heat release had decreased. It is remarkable that the top sediment layers ( 0 to $0.5,0.5$ to $1 \mathrm{~cm}$ ) did not show any significant respiratory activity at in situ temperature on March 6 (Fig. 3), especially since

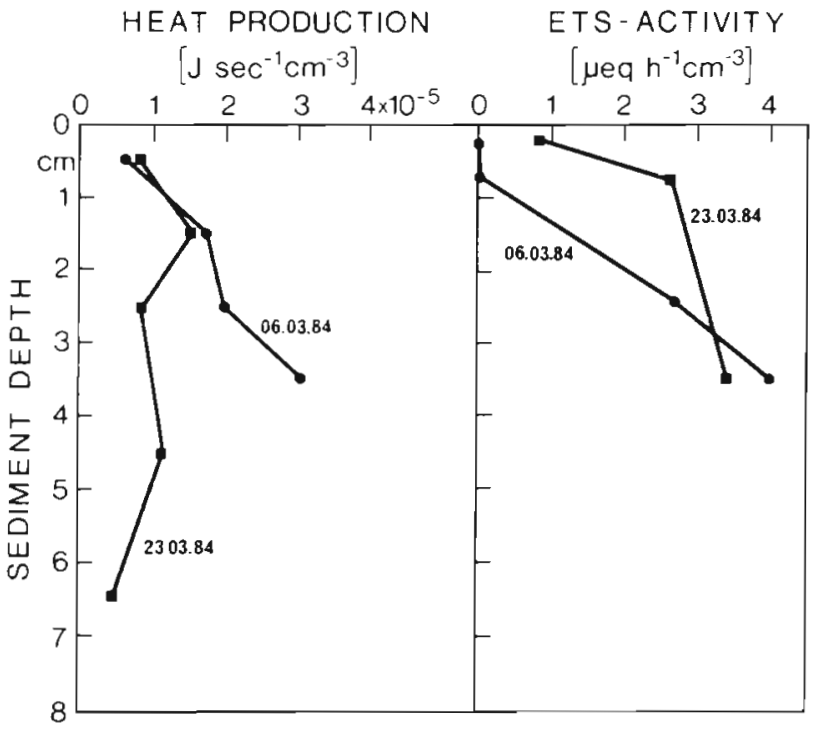

Fig. 3. Heat production and ETS-activity $(n=4)$ in the sediment measured at $2^{\circ} \mathrm{C}$ in situ temperature 
Pollehne (pers. comm.) reported an unusually high oxygen consumption of $400 \mathrm{ml} \mathrm{O}_{2} \mathrm{~m}^{-2} \mathrm{~d}^{-1}$ at this station on this day. On both days ETS-activity increased with depth.

Control experiments at $25^{\circ} \mathrm{C}$ demonstrated that also on March 6 ETS-activity was well measurable in the sediment surface. These results suggested that respiratory activity was temperature limited in the surface layer, but less so in the reduced zone. Therefore, an experiment covering the temperature range 0 to $30^{\circ} \mathrm{C}$ was carried out (Fig. 4). Whereas sediment

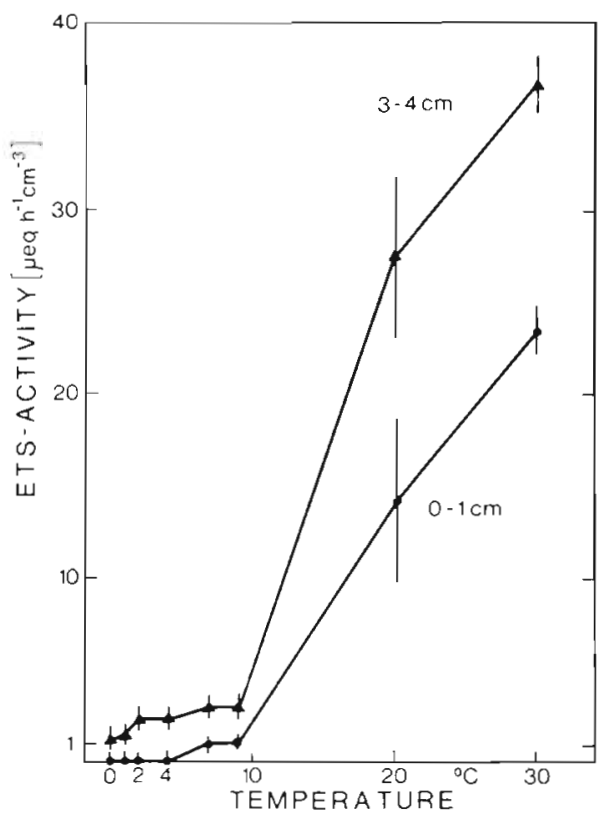

Fig. 4. Sediments from the surface $(0$ to $1 \mathrm{~cm}$ layer) show no detectable ETS-activity ( $\mathrm{n}=4$ ) below $7^{\circ} \mathrm{C}$, while sediment from the reduced zone $(3$ to $4 \mathrm{~cm})$ is active down to $0^{\circ} \mathrm{C}$

from the reduced zone ( 3 to $4 \mathrm{~cm}$ ), containing only half the biomass of the oxidised layer $(0$ to $1 \mathrm{~cm})$, shows measurable activities down to $0^{\circ} \mathrm{C}$, activity in the upper layer was measurable only from $7^{\circ} \mathrm{C}$ upwards. Possibly, there is a critical point between 4 and $7^{\circ} \mathrm{C}$. Neither sample reached maximum ETS-activity at $30^{\circ} \mathrm{C}$

\section{DISCUSSION}

The biochemical method for measuring respiration via the electron transport system was originally used to determine oxygen respiration of planktonic organisms (Packard 1971). Recent investigations demonstrated that the ETS-analysis also responds to nitrate respiration (Packard et al. 1983). In the sediment core presented, nitrate respiration, which can be expected to be of some importance during winter (Sørensen et al. 1979), can only take place in the upper sediment layers
( 0 to $2 \mathrm{~cm}$ ) because nitrate is lacking in deeper layers. At in situ temperature, however, there was no detectable ETS-activity in the top sediment layer (Fig. 3). Unfortunately, no measurements were made in the 1 to $2 \mathrm{~cm}$ layer. Other authors working with sediments have concluded that sulfate respiration might also be measurable; they found positive responses of the method in permanently anoxic sediments (Bengtsson 1982, Vosjan 1982). A generally accepted model of the sulfate respiration chain does not yet exist. Nevertheless, it is known that it is associated with unit membranes and that cytochromes (C3), menaquinone, several ferredoxines and hydrogenases are involved (Wood 1978, Xavier \& Moura 1978, Badziong \& Thauer 1980). The INT reduction process in that electron carrier system is unknown.

If and how long aerobic bacteria survive in anoxic sediments is unknown; hence, a methodological problem must be considered. The extraction procedure is optimized to create a colloidal system of unit membrane vesicles and leads to a redox potential of $>+250 \mathrm{mV}$ in the enzyme assay (Bengtsson 1982). Thus, it is possible that oxygen respiration chains from aerobic bacteria, which may still be present in temporarily anoxic sediments, will also respond positively to the bioassay, although being inactive in situ. In the present study this problem can most likely be excluded, for ETS-activity was below detection limit at in situ temperature in the sediment surface. The principal problem, however, is illustrated in Fig. 4 . While the $Q_{10}$ value of 3 between 0 and $10^{\circ} \mathrm{C}$ is in the normal range, between 10 and $20^{\circ} \mathrm{C}$ it is about 6.1 . This suggests that a mixture of different respiration chains was analysed with different degrees of adaptation to low temperature. One important factor responsible for the increased activity at higher temperatures will obviously be meiofauna burrowing in anoxic sediment layers. From this difficulty and other reasons discussed below it is clear that the ETS-method is not suitable as a replacement for the established tracer technique for sulfate respiration.

Nevertheless, the present hypothesis is that in this case, the ETS-method measured sulfate respiration at in situ temperature. The method, being optimised for oxygen respiration, overestimates real oxygen respiration by a factor 5 to 7 (Christensen \& Packard 1979, Pamatmat et al. 1981). Whether sulfate respiration is underestimated or overestimated is unknown. The other activity parameters, oxygen consumption and heat production, also showed extreme values for a winter period. Heat release of the reduced zone $(2$ to $4 \mathrm{~cm}$ ) will mainly comprise heat production by fermentation and by sulfate respiration. Unfortunately, heat release (enthalpy changes) of sulfate-reducing bacteria are only available for lactate and pyruvate oxidiz- 
ing cultures (Traore et al. 1981), which are less relevant processes in marine sediments (Sørensen et al. 1981). Therefore, an estimation of the importance of fermentation versus sulfate respiration is not yet possible. The lack of activity of respiratory enzymes in the sediment surface in combination with a well-measurable heat release demonstrates the importance of fermentation during periods of low temperature (Graf et al. 1983, Rüger 1984).

Implications of oxygen consumption by the seabed are under heavy discussion (Revsbech et al. 1980). Oxygen consumption by a sediment core may be separated into oxygen respiration, chemosynthesis and chemical oxidation. This investigation gives evidence for the unusual case that oxygen respiration is negligible. The lower detection limit for the ETS-method as used in this study is about $20 \mathrm{ml} \mathrm{O} \mathrm{m}^{-2} \mathrm{~d}^{-1}$, i.e. less than $5 \%$ of the measured $400 \mathrm{ml} \mathrm{O} \mathrm{O}^{-2} \mathrm{~d}^{-1}$. The development of the subsurface ATP-biomass maximum suggests that the oxygen was mainly used for chemosynthetical reactions and chemical oxidations. As mentioned above, the function of respiratory enzymes is bound to unit membranes and their activities are highly sensitive to temperature changes. Especially at low temperature, membranes exhibited critical points at which enzyme reactions are stopped by only a small change in temperature. This phenomenon is explained by changes in the viscosity of certain membrane components, which may crystallize at low temperature (Sinensky 1974, Cossins \& Prosser 1978). Therefore, Somero et al. (1983) postulated specially adapted respiratory enzymes for species living permanently in cold water. Possibly the step between 4 and $7^{\circ} \mathrm{C}$ reflects one such point. In any case the organisms living in the reduced zone were better adapted to low temperature and were still active at $0^{\circ} \mathrm{C}$ with only half the ATP-biomass of the top sediment layer.

Whether this finding represents a special adaptation or a general feature of sulfate respiration remains to be seen. The optima for ETS-activity, not yet reached at $30^{\circ} \mathrm{C}$ (Fig. 4), do not exclude the occurrence of coldadapted species; even psycrophilic bacterial cultures showed ETS-activity maxima between 18 and $40^{\circ} \mathrm{C}$ (Rüger 1984). During winter 1981/82 a maximum in benthic activity at the present station was found during January and February (Graf et al. 1983). This maximum was caused by a winter food supply of undecomposed plankton autumn bloom and macrophyte debris. This input was recorded by protein analysis in the sediment. On March 6, 1984, protein content in the sediments was even higher, and concentrations $>5$ $\mathrm{mg} \mathrm{g}^{-1}$ were found down to $8 \mathrm{~cm}$ sediment depth (Meyer-Reil pers. comm.), i.e. food supply for the benthos was optimal. This finding is one prerequisite for the situation found. Because of prevailing relatively high benthic activities the sediment was not oxidized during winter as found in earlier years (Graf et al. $1982,1983)$. The temporarily increased oxygen supply to the sediment in early March did not stimulate growth of aerobic organisms due to temperature limitation. Therefore, an ATP-biomass maximum, most likely created by chemosynthetic bacteria, immediately above the $\mathrm{Eh}=+100 \mathrm{mV}$ layer could develop. On March 23 this maximum shifted to the sediment surface, with a concomitant decrease in redox conditions.

Acknowledgements. I am indepted to Dr. L.-A. Meyer-Reil and Dr. K.-P. Witzel for helpful comments on the manuscript. This work was supported by the 'Deutsche Forschungsgemeinschaft'.

\section{LITERATURE CITED}

Badziong, W., Thauer, R. K. (1980). Vectorial electron transport in Desulfovibrio vulgaris (Marburg) growing on hydrogen plus sulfate as sole energy source. Arch. Mikrobiol. 125: $167-174$

Bengtsson, W (1982). Aktivität des Elektronen-TransportSystems (ETS) und Wärmeproduktion mariner Sedimente. Ph.D. thesis, Kiel University

Christensen, J. P., Packard, T. T. (1979). Respiratory electron transport activities in phytoplankton and bacteria: Comparison of methods. Limnol. Oceanogr. 24: 576-583

Cossins, A. R., Prosser, C. L. (1978). Evolutionary adaptation of membranes to temperature. Proc. natn. Acad. Sci. U.S.A. 75: 2040-2043

Fenchel, T., Blackburn, T. H. (1979). Bacteria and mineral cycling. Academic Press, London

Graf, G., Bengtsson, W., Diesner, U., Schulz, R., Theede, H. (1982). Benthic response to sedimentation of a spring phytoplankton bloom: process and budget. Mar. Biol. 67: 201-208

Graf, G., Schulz, R., Peinert, R., Meyer-Reil, L.-A. (1983). Benthic response to sedimentation events during autumn to spring at a shallow-water station in the western Kiel Bight. I. Analysis of processes on a community level. Mar. Biol. 77: 235-246

Graf, G., Bengtsson, W (1984). Heat production, activity of the electron-transport-system (ETS), the ratio heat production/ETS-activity, and ATP-turnover as useful tools in benthic ecological field studies. Arch. Hydrobiol. Beih. Ergeb. Limnol. 19: 249-256

Jorgensen, B. B. (1980). Seasonal oxygen depletion in the bottom waters of a Danish fjord and its effect on the benthic community. Oikos 34:68-76

Lowry, O. H., Rosebrough, N. J., Farr, A. L., Randall, R. J. (1951). Protein measurement with the Folin phenol reagent. J. biol. Chem. 193: 265-275

Meyer-Reil, L.-A. (1983). Benthic response to sedimentation events during autumn to spring at a shallow water station in the western Kiel Bight. II. Analysis of benthic bacterial populations. Mar. Biol. 77: 247-256

Packard, T T. (1971). The measurement of respiratory electron transport activity in marine phytoplankton. J. mar. Res. 29: 235-245

Packard, T. T., Garfield, P. C., Martinez, R. (1983). Respiration and respiratory enzyme activity in anaerobic cultures of 
the marine denitrifying bacterium, Pseudomonas perfectomarinus. Deep Sea Res. 30: 227-243

Pamatmat, M. M. (1978). Oxygen uptake and heat production in a metabolic conformer (Littorina irrorata) and a metabolic regulator (Uca pugnax). Mar. Biol. 48: 317-325

Pamatmat, M. M. (1982). Heat production by sediment: Ecological significance. Science 215: 395-397

Pamatmat, M. M., Graf, G., Bengtsson, W., Novak, C. S. (1981). Heat production, ATP concentration, and electron transport activity of marine sediments. Mar. Ecol. Prog. Ser. 4: 135-143

Reimers, T (1976). Anoxische Lebensräume: Struktur und Entwicklung der Mikrobiozönose an der Grenzfläche Meer/Meeresboden. Ph.D. thesis, Kiel University

Revsbech, N. P., Jergensen, B. B., Blackburn, T. H. (1980). Oxygen in the sea bottom measured with a microelectrode. Science 207: 1355-1356

Rüger, H.-J. (1984). Temperature effects on respiratory electron transport system (ETS) in psychrophilic and mesophilic marine bacteria. Veröff. Inst. Meeresforsch. Bremerhaven 20: 29-40

Sinensky, M. (1974). Homeoviscous adaptation - A homeostatic process that regulates the viscosity of membrane lipids in Escherichia coli. Proc. natn. Acad. Sci. U.S.A. 71: $522-525$

Somero, G. N., Siebenaller, J. F., Hochachka, P. W. (1983). Biochemical and physiological adaptations of deep-sea animals. In: Rowe, G. T. (ed.) Deep-sea biology. John Wiley \& Sons, Chichester, p. 261-330

Sørensen, J., Jørgensen, B. B., Revsbech, N. P. (1979). A comparison of oxygen, nitrate, and sulfate respiration in coastal marine sediments. Mar. Ecol. Prog. Ser. 5: 105-115

Sørensen, J., Christensen, D., Jørgensen, B. B. (1981). Volatile fatty acids and hydrogen as substrates for sulfate-reducing bacteria in anaerobic marine sediment. Appl. environ. Microbiol. 42: 5-11

Thiel, H. (1983). Meiobenthos and nanobenthos of the deep sea. In: Rowe, G. T. (ed.) Deep-sea biology. John Wiley \& Sons, Chichester, p. 167-230

Traore, A., Hatchikian, C. E., Belaich, J.-P., Le Gall, J. (1981). Microcalorimetric studies of the growth of sulfate-reducing bacteria: Energetics of Desulfovibrio vulgaris growth. J. Bacteriol. 145: 191-199

Vosjan, J. H. (1982). Respiratory electron transport system activities in marine environments. Hydrobiol. Bull. 16: $61-68$

Wood, P. M. (1978). A chemiosmotic model for sulfate respiration. FEBS Lett. 95: 12-18

Xavier, A. V., Moura, J. G. (1978). NMR studies of electron carrier proteins from sulphate reducing bacteria. Biochemie 60: 327-338

Yingst, J. Y. (1978). Patterns of micro- and meiofauna abundance in marine sediments, measured with the adenosine triphosphate assay. Mar. Biol. 47: 41-54 